\title{
Transmission of Xylella fastidiosa, Causal Agent of Citrus Variegated Chlorosis, by the Glassy-Winged Sharpshooter, Homalodisca coagulata
}

V. D. Damsteegt, Research Plant Pathologist, USDA, ARS, Foreign Disease-Weed Science Research Unit, Ft. Detrick, MD 21702; R. H. Brlansky, Professor, University of Florida, Citrus Research and Education Center, Lake Alfred 33850; P. A. Phillips, Extension Entomologist, University of California, Cooperative Extension, Ventura 93003; and Avijit Roy, Postdoctoral Fellow, University of Florida, Citrus Research and Education Center, Lake Alfred 33850

\begin{abstract}
Damsteegt, V. D., Brlansky, R. H., Phillips, P. A., and Roy, A. 2006. Transmission of Xylella fastidiosa, causal agent of citrus variegated chlorosis, by the glassy-winged sharpshooter, Homalodisca coagulata. Plant Dis. 90:567-570.

Citrus variegated chlorosis (CVC) is an economically important disease of citrus in Brazil and Argentina. The causal pathogen is a strain of Xylella fastidiosa transmitted by several sharpshooter species. The glassy-winged sharpshooter (GWSS), Homalodisca coagulata, has become an important new pest of citrus and grapevines in California, where it transmits X. fastidiosa strains to several crops including grapes, oleander, and almonds. Transmission studies over a 3year period at the USDA BSL3-P containment facility at Fort Detrick, MD, utilizing California field-collected GWSS, a Brazilian strain of CVC, and Madam Vinous sweet orange seedlings, have shown a consistent although low level of transmission of CVC. Test plants were observed for CVC symptoms, analyzed by polymerase chain reaction using species-specific primers for $X$. fastidiosa, membrane entrapment immunofluorescence, and scanning electron microscopy. $X$. fastidiosa was not detected in field-collected GWSS but was detected in GWSS following feeding on CVC-infected source plants. Transmission of the CVC strain of X. fastidiosa by GWSS increases the risk of establishment of CVC in the United States if it were introduced.
\end{abstract}

Additional keywords: plant-pathogenic bacteria, xylem feeders

Citrus variegated chlorosis (CVC) was described as a new disease of citrus in Brazil in 1987 (22,33). The causal agent of CVC was determined to be a fastidious bacterium, Xylella fastidiosa Wells, in the early 1990 s $(8,11,12,17)$. The disease has been reported from Brazil, Argentina, and Costa Rica $(3,11,13)$. Several strains or types of $X$. fastidiosa exist $(26,30)$ that are known to cause diseases of grapes, citrus, coffee, almonds, woody ornamentals, native hardwoods, and alfalfa $(18,19,27,31)$. $X$. fastidiosa strains are transmitted by xylem-feeding sharpshooter species (Ho-

Corresponding author: V. D. Damsteegt E-mail: vern.damsteegt@ars.usda.gov

The use of trade, firm, or corporation names in this publication (or page) is for the information and convenience of the reader. Such use does not constitute an official endorsement or approval by the United States Department of Agriculture or the Agricultural Research Service of any product or service to the exclusion of others that may be suitable.

Accepted for publication 2 December 2005.

\section{DOI: 10.1094/PD-90-0567}

This article is in the public domain and not copyrightable. It may be freely reprinted with customary crediting of the source. The American Phytopathological Society, 2006.
moptera:Cicadellidae, Cicadellinae) (16,32). One of the most studied diseases is Pierce's disease (PD), a limiting factor for grape production in Florida $(21,34)$ and of increasing importance to grape production in California, especially since the introduction of Homalodisca coagulata Say, the glassy-winged sharpshooter (GWSS) (28).

Citrus production in Brazil is considerably reduced by CVC $(19,22)$. Following its initial recognition in 1984 in Argentina (13), where it was known as "pecosita", and in Brazil in 1987 (22), it has spread to all citrus-producing areas of Brazil and in 2003 had infected $43 \%$ of the estimated 200 million trees in the main citrus regions of São Paulo and Minas Gerais (23). Approximately $24 \%$ of symptomatic trees show a brilliant leaf chlorosis and small fruit $(5,20)$. Other symptoms include wilting, canopy dieback, necrotic leaf lesions, zinc-like deficiency, and undersized, hard fruit $(15,19)$. Annual losses exceed $\$ 100$ million in Brazil (19). The CVC strain of $X$. fastidiosa has spread rapidly in South America and has been identified in Costa Rica in 2005 (3). It has the potential to threaten orange production in Central and North America if a suitable vector is available (19).

CVC has been experimentally transmitted by 11 different sharpshooter species tested in Brazil (16). Sharpshooters are ubiquitous pests in citrus production areas of Florida and California $(1,2,25)$. Oncometopia nigricans Walker, a sharpshooter associated with citrus in Florida, has been demonstrated as an efficient vector of CVC (7). Another sharpshooter, the glassy-winged sharpshooter, Homalodisca coagulata Say, is a native, ubiquitous pest of grapes in the southeastern United States, Texas, and since 1990 has become established in southern and central California, where it threatens the grape industry by its role in the spread of PD $(19,25)$. It has been shown to transmit several pathotypes of $X$. fastidiosa $(6,29)$.

We initiated a project in 1999 to investigate the potential of naturally occurring GWSS collected in California to transmit $\mathrm{CVC}$, and we are reporting here the results of that transmission project. This information is important to assess the threat posed by CVC to citrus production in the United States. Portions of this study have been reported elsewhere (14).

\section{MATERIALS AND METHODS}

Plant materials. Sweet orange plants (Citrus sinensis L. cv. Madam Vinous) infected with CVC were established and maintained in the BSL3-P biosafety containment facility at Fort Detrick, MD, under APHIS permit 39609. The CVC isolates originated from buds taken from infected sweet orange trees from Brazil and grafted into healthy 'Madam Vinous' sweet orange trees at the Exotic Pathogens of Citrus Collection, USDA, ARS, Beltsville, MD (John Hartung, personal communication). The sweet orange plants were confirmed positive for the CVC strain of $X$. fastidiosa by polymerase chain reaction (PCR) assay (26) prior to being used as source plants.

Sharpshooter collection and transmission. GWSS were collected from Eureka or Lisbon lemon trees in Ventura Co., CA, between 1999 and 2002. The sharpshooters were shaken from trees, weekly or biweekly, collected into a holding container, and transferred in groups of 6 to 10 adults into individual plant tubular cages $(3 \times 15$ $\mathrm{cm})$ containing either rough lemon cuttings or rooted sour orange seedlings. Tubes were sealed with mailing tape, packed in groups of five into mailing boxes, and shipped overnight to the BSL3-P facility at 
Fort Detrick. A total of 137 shipments, 1,100 cages, and 7,950 GWSS adults were shipped. Upon arrival from California, the transport boxes were opened in the containment facility, and all surviving insects were allowed to acclimatize for $24 \mathrm{~h}$ on one large sweet orange plant. This plant became the negative control for determining the presence of Xylella in shipped sharpshooters. Insects surviving the first $24 \mathrm{~h}$ were transferred into a nylon sleeve cage surrounding an infected branch of a CVC-infected source plant for a 48- to 72$\mathrm{h}$ acquisition access period (AAP). At the end of each AAP, living adult GWSS were orange seedling for an inoculation access period (IAP). Because a large percentage of GWSS that survived shipment and 24-h acclimatization did not actively feed on the infected source plant, adults from several shipments were added sequentially to the same sweet orange test seedlings until at least 30 had been observed feeding for at least $48 \mathrm{~h}$. Daily survival counts were made from the date of arrival from California until the death of all insects on the test seedlings. Inoculated sweet orange seedlings then were removed from the inoculation cage and placed onto a greenhouse bench and observed for symptom development.

Test plants were subjected to 16 -h day length by natural sunlight and supplemental lighting with high-pressure sodium lamps. Greenhouse temperatures ranged from 18 to $25^{\circ} \mathrm{C}$. Plants were fertilized monthly with Peters 20N-20P-20K (Grace Sierra Horticultural Products Co., Milpitas, CA) and Osmocote (Scott-Sierra Horticultural Products Company, Marysville, $\mathrm{OH}$ ).

Evaluation assays. All 26 inoculated test plants, uninoculated controls (two sweet orange seedlings on which newly arrived GWSS were allowed to feed), and three sweet orange seedlings bud-grafted from the CVC source plant were monitransferred onto a caged healthy sweet

tored visually for abnormal growth, chlorotic spotting, or other evidence of disease on a monthly basis. Date of symptom development and type of symptoms were recorded.

Symptomatic and asymptomatic plants were assayed for the presence of the CVC strain of Xylella by polymerase chain reaction (PCR) (26). Six to eight leaves, selected from different branches of each test plant and control plants, were collected. Petioles and part of the midribs were excised, sliced, DNA extracted using the DNeasy kit by Qiagen, Inc., Valencia, CA, and assayed using specific primers CVC-1 and 272-2-int designed exclusively to detect the CVC strain of $X$. fastidiosa (26) producing an amplicon of $500 \mathrm{bp}$.

Subsamples of the same leaves used in PCR also were assayed by membrane entrapment immunofluorescence (MEIF) that had been designed for detection of the citrus canker bacterium (9) and previously used for the CVC X. fastidiosa (17). Samples were pulverized in extraction buffer and passed through MEIF columns containing membranes to trap the bacteria. Membranes were incubated in polyclonal antibodies (UF-26) made against X. fastidiosa by Cocalico Biologicals, Inc., Reamstown, PA, labeled with a secondary tetramethylrhodamine isothiocyanate fluorescent-labeled goat anti-rabbit antibody, mounted on glass slides, and viewed with a light microscope with a fluorescent attachment (exciter BP 546, beam splitter FT 580, and barrier LP 590) in the green excitation range.

Leaf petioles of the six plants testing positive by PCR and MEIF, cibarial pumps, and precibaria from 27 GWSS that had fed on CVC-infected tissue, healthy sweet orange leaf petioles, and GWSS controls were examined for evidence of bacterial cells by scanning electron microscopy (SEM). GWSS were killed by freezing at $-20^{\circ} \mathrm{C}$ and fixed in $3 \%$ glu-

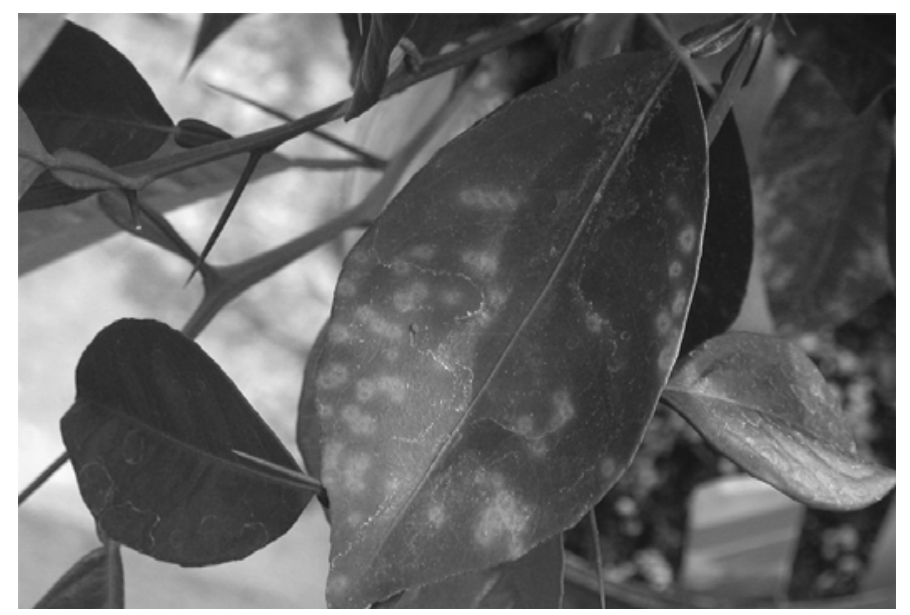

Fig. 1. Symptoms of citrus variegated chlorosis in 'Madam Vinous' sweet orange inoculated by the glassy-winged sharpshooter consisted of diffuse chlorotic mottle and definitive chlorotic spots on the upper epidermis and rust-colored spots on lower epidermis of lower leaves. Water marks are not part of the symptoms. taraldehyde for $8 \mathrm{~h}$. The heads were removed, postfixed in $1 \%$ osmium tetroxide, dehydrated in an acetone series, and critical point dried. Cibaria and diaphragms were dissected from the dried heads, mounted on SEM stubs, sputter-coated with gold-palladium, and viewed on a Hitachi S530 scanning electron microscope (10).

\section{RESULTS}

Sharpshooter collection and transmission. Sequential addition of GWSS from the source plant to test plants from successive shipments resulted in 26 sweet orange plants having had at least 30 sharpshooters living and feeding $48 \mathrm{~h}$ or longer. Most GWSS that were transferred to the test plants did not feed or extrude any xylem fluid before dying. Ten test plants died during the test period from undetermined causes and the evaluation assays were conducted on the 16 remaining sweet orange plants.

Evaluation assays. Symptom expression of CVC in our greenhouse-grown sweet orange plants consisted of bright chlorotic spots on the older leaves of six of 16 plants, 9 months after the last GWSS had fed (Fig. 1), and a more diffuse chlorotic mottle on younger leaves. The chlorotic spots only appeared on the lower, older leaves and not on all branches. The spots were bright yellow on the upper epidermis with rust-colored spots on the lower epidermis directly opposite the chlorotic spots. An additional three plants only showed a chlorotic mottle of the younger leaves (Table 1).

The 16 test plants inoculated by GWSS and the grafted, positive controls were assayed for the presence of the CVC strain of Xylella by PCR, 12 or more months after the final inoculation feeding by GWSS. Only the six plants that produced distinctive chlorotic spotting were positive by PCR, as evidenced by a 500-bp product (data not shown). The amplicons were not sequenced.

The six test plants positive by PCR also were positive by MEIF analysis with large numbers of fluorescing bacteria. An additional three test plants with only diffuse chlorotic mottling had a few fluorescent bacteria (Table 1). Seven of the 16 orange plants were negative in all assays. Three positive control plants inoculated by chip budding from the CVC source plant developed chlorotic spotting and were positive by MEIF and PCR. The two noninoculated control plants were negative.

Scanning electron micrographs of xylem vessels from the six CVC-infected sweet orange seedlings with chlorotic spotting and from cibaria of 27 sharpshooters having fed on infected source plants revealed abundant bacterial populations (Fig. 2). No bacteria were found in 25 randomly chosen field-collected GWSS or in healthy sweet orange seedlings. 


\section{DISCUSSION}

The purpose of our project was to determine transmissibility of the CVC strain of $X$. fastidiosa by the GWSS. The CVC strain of $X$. fastidiosa is not in the United States, and all transmission studies had to be done in a quarantine containment facility such as the BSL-3P facility at Fort Detrick, MD. This required moving the field-collected GWSS 3,000 miles by overnight carrier with drastic changes in the environment while maintaining the proper moisture levels in their bodies. More than $90 \%$ of the 7,950 adult GWSS that arrived in the Fort Detrick Laboratory alive and seemingly hydrated, never resumed active feeding on succulent sweet orange tissue and died within $72 \mathrm{~h}$ and probably did not play a role in transmission. For this reason, we sequentially added sharpshooters from several shipments to the same test plant to arrive at an arbitrarily selected minimum of 30 actively feeding GWSS for at least $48 \mathrm{~h}$ as an inoculation set.

In contrast to the efficiency studies with O. nigricans (7), in which one sharpshooter could transmit CVC at a $20 \%$ level, we obtained limited transmission with 30 actively feeding $H$. coagulata. Except for plants 3, 5, and 6 (Table 1), all plants positive by MEIF also were positive by PCR. In plants 3, 5, and 6, the symptoms were a diffuse chlorotic mottle without the distinct chlorotic spotting noted in the other positives. The MEIF polyclonal antibodies were raised against the $X$. fastidiosa species and not specifically against the CVC strain. The PCR primers used were specific to the CVC strain of $X$. fastidiosa (26). Although we did not detect any bacteria in "healthy" $H$. coagulata, the few bacteria visualized in the MEIF analyses of plants 3, 5, and 6 may have been another strain of $X$. fastidiosa.

Studies by Oliveira et al. (24) utilizing quantitative real-time PCR indicated that $X$. fastidiosa concentrations were greater in older leaves, and strong symptoms seen during summer months were in leaves colonized as young leaves in the early spring. Our results with greenhousegrown, sharpshooter-inoculated sweet orange seedling trees were similar. Actively feeding $H$. coagulata inoculated susceptible 'Madam Vinous' seedlings, but symptoms did not appear until almost 9 months later when the inoculated leaves had become the older leaves on the young trees. Young leaves were asymptomatic, but as each new growth spurt occurred, the older leaves at that point would become vividly symptomatic (Fig. 1). Almeida and Purcell (4) found low bacterial populations in almond associated with low transmission of $X$. fastidiosa by sharpshooters. They speculated that the low bacterial populations of almond strain of $X$. fastidiosa in almond and the CVC strain in citrus may have similar transmission effects with $H$. coagulata. Our low transmis- sion efficiency of the CVC strain of $X$. fastidiosa may support that hypothesis, although further research is necessary. We do not have any data on bacterial popula-

tions per se to separate transmission efficiency from feeding efficiency.

The statement by Hopkins and Purcell (19) that X. fastidiosa could become seri-

Table 1. Results of citrus variegated chlorosis (CVC) inoculations by glassy-winged sharpshooter (GWSS) feeding

\begin{tabular}{|c|c|c|c|c|}
\hline Test plant no. & Visual symptoms ${ }^{a}$ & $\mathbf{P C R}^{\mathbf{b}}$ & MEIF $^{c}$ & $\begin{array}{c}\text { Inoculation } \\
\text { method }\end{array}$ \\
\hline 1 Grafted control & Chlorotic spotting & + & + & Grafted \\
\hline 2 & Chlorotic spotting & + & + & GWSS \\
\hline 3 & Chlorotic mottle & - & + & GWSS \\
\hline 4 & Chlorotic spotting & + & + & GWSS \\
\hline 5 & Chlorotic mottle & - & + & GWSS \\
\hline 6 & Chlorotic mottle & - & + & GWSS \\
\hline 7 & Chlorotic spotting & + & + & GWSS \\
\hline 8 & Chlorotic spotting & + & + & GWSS \\
\hline 9 & Chlorotic spotting & + & + & GWSS \\
\hline 10 & Chlorotic spotting & + & + & GWSS \\
\hline CVC source plant & Chlorotic spotting & + & + & Grafted \\
\hline Negative control & None & - & - & GWSS $^{\mathrm{d}}$ \\
\hline
\end{tabular}

a Chlorotic spotting of the older leaves as seen in Figure 1; chlorotic mottle is a diffuse yellow mottle seen on younger leaves of all positive plants.

${ }^{\mathrm{b}}$ Polymerase chain reaction using the primer pair CVC-1/272-1-int.

${ }^{\mathrm{c}}$ Membrane entrapment immunofluorescence.

${ }^{\mathrm{d}}$ GWSS not fed on the CVC source plant.
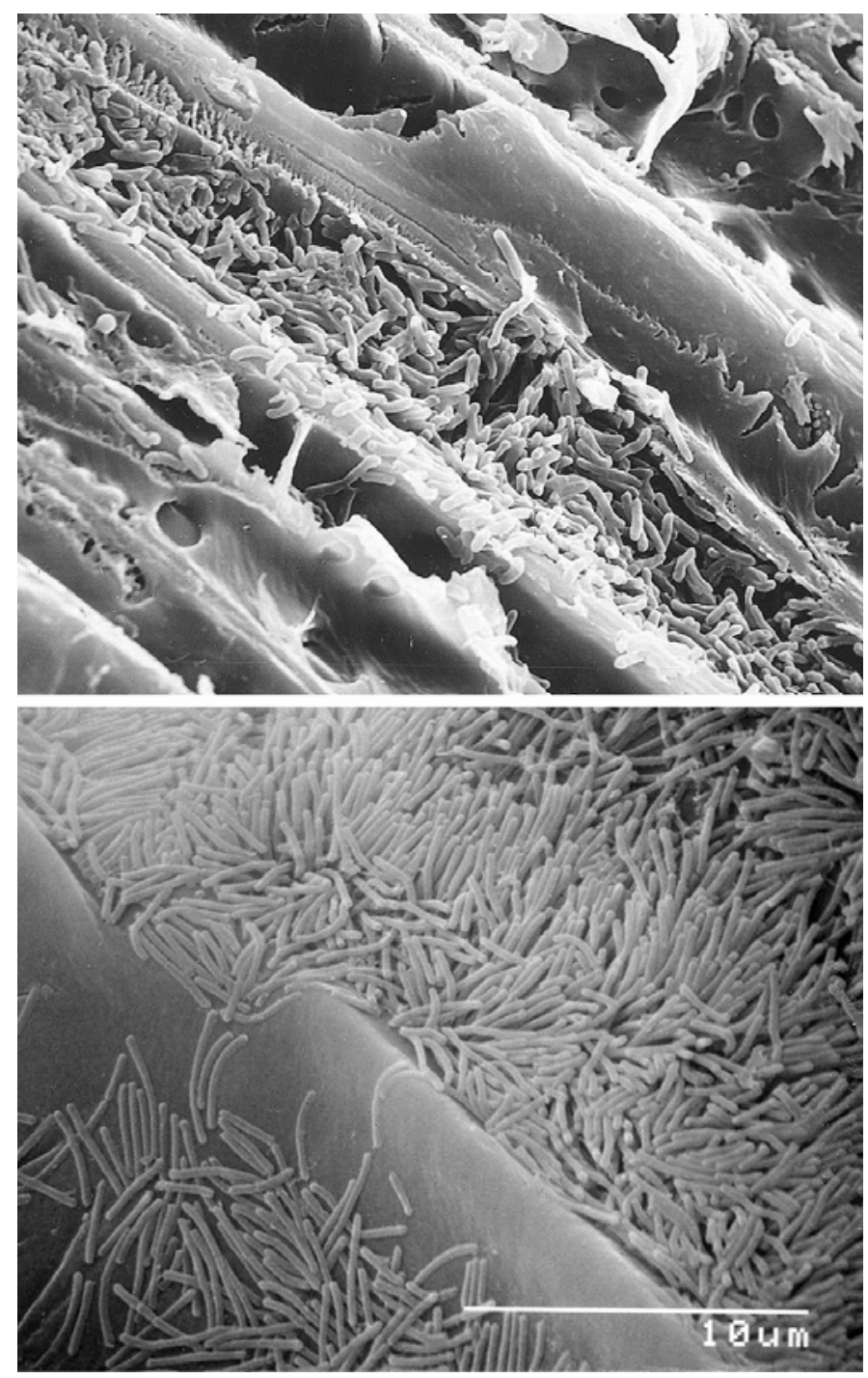

Fig. 2. Scanning electron micrographs exhibiting Xylella fastidiosa in: top, xylem vessels from an infected sweet orange seedling; and bottom, cibarium of a glassy-winged sharpshooter after having fed on a citrus variegated chlorosis-infected sweet orange plant. 
ous, even crop-limiting, in areas where a vector exists, heightens the threat of CVC to the citrus-growing areas of North America where $H$. coagulata has become established, such as Florida, Texas, and California.

\section{ACKNOWLEDGMENTS}

We acknowledge the excellent technical assistance of Ms. Sandra Sorensen and Ms. Jenna Miller for insect handling and plant maintenance, and Ms. Debbie Howd for laboratory assistance in conducting MEIF assays and SEM. We thank the Hansen Trust Fund and the California Citrus Research Board for financial assistance.

\section{LITERATURE CITED}

1. Adlerz, W. C. 1980. Ecological observations on two leafhoppers that transmit the Pierce's disease bacterium. Proc. Fla. State Hortic. Soc. 93:115-120.

2. Adlerz, W. C., and Hopkins, D. L. 1979. Natural infectivity of two sharpshooter vectors of Pierce's disease of grape in Florida. J. Econ. Entomol. 72:916-919.

3. Aguilar, E., Villalobos, W., Moreira, L., Rodriguez, C. M., Kitajima, E. W., and Rivera, C. 2005. First report of Xylella fastidiosa infecting citrus in Costa Rica. Plant Dis. 89:687.

4. Almeida, R. P. P., and Purcell, A. H. 2003. Homalodisca coagulata (Hemiptera, Cicadellidae) transmission of Xylella fastidiosa to almond. Plant Dis. 87:1255-1259.

5. Anonymous. 2000. CVC: Sintomas estão mais graves. Rev. Funde-citrus 99:8-9.

6. Blua, M. J., Phillips, P. A., and Redak, R. A. 1999. A new sharpshooter threatens both crops and ornamentals. Calif. Agric. 53:22-25.

7. Brlansky, R. H., Damsteegt, V. D., and Hartung, J. S. 2002. Transmission of the citrus variegated chlorosis bacterium Xylella fastidiosa with the sharpshooter Oncometopia nigricans. Plant Dis. 86:1237-1239.

8. Brlansky, R. H., Davis, C. L., Timmer, L. W., Howd, D. S., and Contreras, J. 1991. Xylemlimited bacteria in citrus from Argentina with symptoms of citrus variegated chlorosis. (Abstr.) Phytopathology 81:1210.

9. Brlansky, R. H., Lee, R. F., and Civerolo, E. L. 1990. Detection of Xanthomonas campestris and $X$. citri from citrus using membrane entrapment immunofluorescence. Plant Dis. 74:863-868.

10. Brlansky, R. H., Timmer, L. W., French, W. J., and McCoy, R. E. 1983. Colonization of the sharpshooter vectors, Oncometopia nigricans and Homalodisca coagulata, by xylem-limited bacteria. Phytopathology 73:530-535.

11. Chagas, C. M., Rossetti, V., and Beretta, M. J. G. 1992. Electron microscopy studies of a xylem-limited bacteria in sweet orange affected with citrus variegated chlorosis disease in Brazil. J. Phytopathol. 134:306-312.

12. Chang, C. J., Garnier, M., Zreik, L., Rossetti, V., and Bove, J. M. 1993. Culture and serological detection of the xylem-limited bacterium causing citrus variegated chlorosis and its identification as a strain of Xylella fastidiosa. Curr. Microbiol. 27:137-142.

13. Contreras, J. D. V. 1992. Pecosita ou falsa mancha grasienta na Argentina. Laranja Cia 31:4.

14. Damsteegt, V. D., Brlansky, R. H., Phillips, P. A., and Roy, A. 2003. Glassy-winged sharpshooter transmission of Xylella fastidiosa, causal agent of citrus variegated chlorosis. (Abstr.) Phytopathology 93S:19.

15. Derrick, K. S., and Timmer, L. W. 2000. Citrus blight and other diseases of recalcitrant etiology. Annu. Rev. Phytopathol. 38:181-205.

16. Fundecitrus. 2000. Manual de convivência com a CVC. Fundo Paulista de Defesa da Citricultura, Araraquara, Brazil.

17. Hartung, J. S., Beretta, J., Brlansky, R. H., Spisso, J., and Lee, R. F. 1994. Citrus variegated chlorosis bacterium: Axenic culture, pathogenicity, and serological relationships with other strains of Xylella fastidiosa. Phytopathology 84:591-597.

18. Hopkins, D. L. 1989. Xylella fastidiosa: Xylem-limited bacterial pathogen of plants. Annu. Rev. Phytopathol. 27:271-290.

19. Hopkins, D. L., and Purcell, A. H. 2002. Xylella fastidiosa: Cause of Pierce's disease of grapevine and other emergent diseases. Plant Dis. 86:1056-1066.

20. Laranjeira, F. F., Pompeu, J., Jr., Harakava, R., Figueiredo, J. O., Carvalho, S. A., and Coletta Filho, H. D. 1998. Cultivares e espécies cítricas hospedeiras de Xylella fastidiosa em condicões de campo. Fitopatol. Bras. 23:147154.

21. Lee, R. F., Beretta, M. J. G., Hartung, J. H., Hooker, M. E., and Derrick, K. S. 1993. Citrus variegated chlorosis: Confirmation of Xylella fastidiosa as the causal agent. Summa Phytopathol. 19:123-125

22. Lee, R. F., Derrick, K. S., Beretta, M. J. G., Chagas, C. M., and Rossetti, V. 1991. Citrus variegated chlorosis: A new destructive disease of citrus in Brazil. Citrus Ind. 72:12, 13, 15.
23. Lopes, S. A., Teixeira, D. C., Fernandes, N. G Ayres, A. J., Torres, S. C. Z., Barbosa, J. C. and Li, W. B. 2005. An experimental inoculation system to study citrus-Xylella fastidiosa interactions. Plant Dis. 89:250-254.

24. Oliveira, A. C., Vallim, M. A., Semighini, C. P., Araujo, W. L., Goldman, G. H., and Machado, M. A. 2002. Quantification of $X y$ lella fastidiosa from citrus trees by real-time polymerase chain reaction assay. Phytopathology 92:1048-1054.

25. Phillips, P. A. 1999. Vineyards, almond orchards threatened. Fruit Grow. 119:18F-18H.

26. Pooler, M. R., and Hartung, J. S. 1995. Specific PCR detection and identification of $X y$ lella fastidiosa strains causing citrus variegated chlorosis. Curr. Microbiol. 31:377-381.

27. Purcell, A. H. 1996. Fastidious xylem-limited bacterial plant pathogens. Annu. Rev. Phytopathol. 34:131-151.

28. Purcell, A. H., and Saunders, S. R. 1999. Glassy-winged sharpshooters expected to increase plant disease. Calif. Agric. 53:26-27.

29. Purcell, A. H., Saunders, S. R., Hendson, M. Grebus, M. E., and Henry, M. J. 1999. Causal role of Xylella fastidiosa in Oleander leaf scorch disease. Phytopathology 89:53-58.

30. Qin, X., Miranda, V. S., Machado, M. A., Lemos, E. G. M., and Hartung, J. S. 2001. An evaluation of genetic diversity of Xylella fastidiosa isolated from diseased citrus and coffee in São Paulo, Brazil. Phytopathology 91:599605.

31. Redak, R. A., Purcell, A. H., Lopes, J. R. S Blua, M. J., Mizell, R. F., III, and Andersen, P. C. 2004. The biology of xylem fluid-feeding insect vectors of Xylella fastidiosa and their relation to disease epidemiology. Annu. Rev. Entomol. 49:243-270.

32. Roberto, S. R., Coutinho, A., Lima, J. E. O., Miranda, V. S., and Carlos, E. F. 1996. Transmissão do Xylella fastidiosa pelas cigarrinhas Dilobopterus costalimai, Acrogonia terminalis, e Oncometopia facialis (Hemiptera: Cicadellidae) em citros. Fitopatol. Bras. 21:517-518.

33. Rossetti, V., Garnier, M., Bove, J. M., Beretta, M. J. G., Teixlira, A. R. R., Quaggio, J. A., and deNegri, J. D. 1990. Presence de bacteries dans le xyleme d'orangers atteints de chlorose variegee, unenovelle maladie des agrumes au Brasil. C. R. Acad. Sci. (Paris) 310:345-349.

34. Stoner, W. N., Stover, L. H., and Parris, G. K. 1951. Field and laboratory investigations indicate grape degeneration in Florida is due to Pierce's disease virus infection. Plant Dis. Rep. 35:341-344. 